\title{
Keratin, Type II Cytoskeletal 8
}

National Cancer Institute

\section{Source}

National Cancer Institute. Keratin, Type II Cytoskeletal 8. NCI Thesaurus. Code C126964.

Keratin, type II cytoskeletal 8 (483 aa, $\sim 54 \mathrm{kDa}$ ) is encoded by the human KRT 8 gene.

This protein is involved in maintaining the structure of striated muscles and simple epithelia. 